\title{
PRINCIPALS' SCHOOL PLANT MANAGEMENT STRATEGIES, AS PERCEIVED BY PARENT-TEACHER-ASSOCIATION EXECUTIVES IN NIGERIAN PUBLIC SCHOOLS.
}

\author{
IJEKPA, BENEDICTA ADA and MKPA AGU MKPA \\ ABIA STATE UNIVERSITY, UTURU \\ EMAIL: ijekpai450@gmail.com, mamkpa2000@yahoo.com
}

\begin{abstract}
This descriptive survey study examines how Parent-Teacher Association (P.T.A) Executives perceive principals' school plant management strategies in public secondary schools in south east states, of Nigeria in the areas of damage restitutions, effective monitoring, maintenance culture, establishment of a maintenance workshop, encouragement of community participation, and setting aside equipment fee for plant maintenance. Six research questions and three hypotheses guided the study. The subjects consisted of 3,344. P.TA executives and 239 principals' randomly and proportionately drawn from public schools in the five south-eastern states of Nigeria. The instrument for data collection was a researcher made 35 item questionnaire "PTA Executives' Perception of Principals' Management Strategies of School Plant Questionnaire" validated and with a reliability index of 0.08 using the Pearson's Product Moment Correlation Coefficient Statistics. Data were collected using five trained research assistants who returned with a total of 3500 properly filled copies of the questionnaire. Means and percentages were used to analyze data related to the research questions while the t-test was used to test the hypotheses. Results revealed that the PTA executives and Principals' agree on the need to apply the strategies of restitution for damages, setting aside equipment fee, and effective monitoring of school plant. They both disagree on the strategy of setting up of maintenance workshop. On the idea of community participation in school plant maintenance, the PTA agrees, but Principals' disagree" The paper concludes that while a properly managed school plant contributes to the achievement of stated goals, certain factors including principals' management strategies, PTA oversight, school location and size impact must be improved for this to happen.
\end{abstract}

Keywords: School Plants, Management Strategies, Principals, Parent-Teacher Association, Perception 


\section{INTRODUCTION}

Principals of secondary schools play very vital roles in the realization of educational goals. The National Policy on Education (FRN, 2013) outlined the objectives of secondary school education to include among others to inspire students with the desire for self-improvement and achievement of excellence. In order to achieve these laudable goals and objectives, secondary schools need effective management and leadership. They need school administrators (principals) who can mobilize parents, teachers, students and other stakeholders to get involved meaningfully in the school system. Eziuzo and Enueme (2013) have stated that the Federal Republic of Nigeria in her National Policy on Education (FRN, 2013) encourages local people, particularly parents to participate in school management.

In consonance, Idoko (2005) affirms that one of the primary functions of secondary school principals is management and maintenance of school plant because the success or failure of the educational system depends on the judicious management of schools by the said principals. Okorie, Igwe, Asodike, Onyeike and Anyaogu (2014) also affirmed that the success of educational system lies strongly on the relationship exhibited by various members of the Parent-Teacher-Association (PTA)

Agboneye (2006) posited that school plants are the physical resources or physical facilities, and which Asiabaka (2008) included all types of buildings for teaching and non- teaching activities, equipment for academic and non-academic activities, areas for sports and games, landscape, farms and garden including trees, roads and paths. Others include furniture, toilet and storage facilities, lighting, acoustics, packing lot, security, transportation, ICT, food services, cleaning materials and special facilities for the physically challenged. These facilities are necessary for the achievement of educational goals and objectives because they satisfy the physical and emotional needs of students and teachers of the school. Therefore their availability, adequacy and relevance influence efficiency and high productivity.

School plant has been influenced by some factors which include

1. Principal's management strategy of school plant

2. PTA management strategy of school plant

3. School location and size impact of school plant.

- Principal's Management Strategies of School Plant - Asodike, Ebong, Oluwuo, and Abraham (2013) stated that management of school plant sums up all the strategies put in place for maintenance, ensuring effective and prompt utility, adequate supply and avoiding wastage, ensuring educational facilities are properly used to achieve the stated goals. Uko (2015) viewed that effective management of school plant is important in creating the enabling conducive academic environment in order to enhance achievement and performance in teaching and learning. He suggested that qualified and competent professionals should be appointed as principals. Government should set up a cammititęe or 
agency to oversee, supervise and monitor the facilities, while principals, teachers and students should emulate maintenance culture in handling of educational facilities.

However, according to Amanchukwu and Ololube (2015) management of school plant requires good leadership, effective monitoring culture, preventive and predictive maintenance etc. and viewed the problem of school plant management to include: overcrowding, non-delegation of tasks by the principal to staff, vandalism of property. He suggested the following for effective management of school plant: involvement of PTA, community stakeholders, staff and students, periodic inspection, principals not to give out any part of the school plant for commercial purpose.

- PTA Management of School Plant - Parents play the role of inculcating discipline and knowledge to their children, as well as giving them the best in life, like quality education. Parents perform the function of contributing in making curricular development policy and setting standards in school. The PTA meeting is a forum for teachers and parents to interact; enlighten parents on discipline and causes of students' delinquency, parents have insight to the causes of students' problems and know the effective ways to deal with the problems. Through the PTA, teachers and school management have insight into the background of their students. The Federal Republic of Nigeria recognized the importance of parents involvement in school management and stated that close participation and involvement of communities at the local level in the administration and management of school will be encouraged (FRN, 2013). Onderi \& Makor (2013) accepted that PTA provides a link through which parents and the rest of the community assume a partnership responsibility and participation of the children. Eziuzo and Enueme (2013) reported a special situation where school PTA in Ghana, made an effort to contact parents of dropped out children. They also posited that in Kenya, PTA is involved in school programs, monitoring educational services and in South Africa and other continents PTAs provide personal hygiene facilities. Okendo (2012) also regarded PTA as one of the community agencies in the educational system. Tshabalala (2013) observes that parents are expected to contribute to the management of school facilities, raise funds for the projects, assist in maintenance, discipline, and attend school activities and PTA meetings regularly. He also reported that strong leadership from school heads establish parent-friendly schools, regular home- school community and innovative parent volunteering, and concluded that parents' participation in school management compliments government effort in the provision and maintenance of school infrastructure. Ezeigbo (2011) in Asodike et al (2013) noted that PTA is a major stakeholder in education with a mission to re-awaken and revive parents' participation in order to strengthen the basis or foundation for a sustainable national development.

- School Location and Size Impact on Management of School Plant - Asodike et al. (2013) are of the view that the school site (school premises) should be fenced to avoid trespassing by community members to avoid confrontation and conflict between the school and the community. Koroye (2016) viewed that the size of classroom, playground and availability of material resources in relation to the number of students in schools, could affectivearning. 
He continued that some schools in rural and urban areas lack adequate infrastructural facilities like classroom, seeing some students learning under trees. In some cases existing facilities were dilapidated or destroyed. Mbipom (2010) cited in Koroye (2016) said that in rural schools that have small population, interactions are personal, while urban schools have individualistic life without any form of permanency. Also Ogili (2009) cited in Koroye (2016) stated that rural people have low income and are generally poor. They engage in subsistent farming while the urban populations are mostly civil servants, traders and artisans. This implies that the rural location has poor accessibility of modern educational facilities, and this is a hindrance to the rural child in learning. Amanchukwu and Ololube (2015) believes that the location of a school is a determining factor in school plant planning. Schools could be located in rural, semi-rural, urban or metropolis, however, the school location could affect the principals' management strategies.

Management of school plant in secondary schools by principals for effective implementation of educational objectives in Nigeria is an intellectually demanding job. Therefore, the school principal needs talent in his activities of educational management. For instance, teaching and learning take place in a conducive classroom. Experiments are performed in the laboratory, including the storing of chemicals and equipment. Books, magazines, newspapers, journal and other materials are also stored in the libraries to ensure the realization of educational objectives. However, where these school plant are inadequate, not supplied and maintained, teaching and learning processes will be hampered. In the south east states of Nigeria, there are many dilapidated structures like classrooms, libraries, machines, materials etc. It had been alleged that principals are not involved in the planning and construction of these facilities. Olagboye (2004) confirmed this view that most school heads hardly had the opportunity to participate in the planning, the site selection and construction of the school and this hampers the school heads in their maintenance. Meghan (2001) accepted that principals and teachers were brought into the construction process too late to have significant impact which resulted in building designs that do not meet professional standards. Nwosu (2008) opined that the school authority, principals and school board, should determine the type of school to set up and the choice of location. It is the duty of the school principal to see to the effective management of school plants. He can adopt any strategy of his choice such as restitution for damages, not giving out any part of the school plant for commercial purpose, effective monitoring, community participation etc. The PTA executive members being one of the stakeholders of the school have the responsibility to assist the principal in whatever strategy he adopts. 


\subsection{The Problem :}

The problem of this study put in question form is: How do the PTA executive members perceive the school plant management strategies of their principals in the public secondary schools in south eastern states of Nigeria- Abia, Anambra, Ebonyi, Enugu and Imo?

\subsection{Research Questions:}

To guide the study, the following research questions were raised

(1) How do PTA executive members and principals perceive restitution for damages as principals' school plant management strategy?

(2) How do PTA executive members and principals perceive effective monitoring as principals' school plant management strategy?

(3) How do PTA executive members and principals perceive setting aside equipment fee as principals' school plant management strategy?

(4) How do PTA executive members and principals perceive maintenance culture as principals' school plant management strategy?

(5) How do PTA executive members and principals perceive setting up maintenance workshop as principals' school plant management strategy?

(6) How do PTA executive members and principals perceive community participation as principals' school plant management strategy?

\subsection{Hypotheses:}

The following hypotheses were tested at 0.05 level of significance.

(1) There is no significant difference in the perception of male and female PTA executive members on community participation as principals' school plant management strategy.

(2) There is no significant difference in the perception of male and female PTA executive members on setting aside equipment fee as principals' school plant management strategy.

(3) There is no significant difference, in the perception of Imo and Anambra states PTA executive members on principals' school plant management strategy.

\subsection{METHODOLOGY}

The study was a survey research. It was aimed to identify the Parent-Teacher Association (PTA) Executives' and principals' perception of principals' school plant management strategies. The study was designed to use questions to examine the extent the parent- teacher association (PTA) executives and principals perceive the principals' school plant management strategies of - restitution for damages, effective monitoring, setting aside equipment fee, maintenance culture, setting up of maintenance workshop and vreoinmimgenity 
participation. The variables for the study were gender and state of domicile. The study was carried out in south east states of Nigeria. The target population of the study was 17,910 ; comprising 16,716 identified PTA executive committee members and 1,194 principals in all public secondary schools in south east states of Nigeria. The sample for this study consists of 3,583 persons comprising 3,344 PTA executive members and 239 principals drawn through a proportionate; stratified random sampling technique.

A researcher-developed instrument "Parent-Teacher Association Executive's Perception of Principals' Management Strategies of School Plant Questionnaire” (PTAPPMSSPQ) was used for data collection. The PTAPPMSSPQ had two sections, A \& B. Section A has three items and sought for the bio data of the respondents. Section B has thirty five items and sought for principal's school plant management strategies. These thirty five items were all structured on a four point Likert type scale of strongly agree (4 points), agree (3 points), disagree ( 2 points) and strongly disagree ( 1 point). Face and content validations of PTAPPMSSPQ were ascertained by experts in the fields of Educational Administration and Planning and Measurement and Evaluation. Pearson Product Moment correlation coefficient of 0.80 was obtained for PTAPPMSSPQ by administering the instrument twice with a two weeks interval on 60 PTA executive members and 20 principals who were not part of the sample by the researchers and 5 trained assistants. The researchers working with the five research assistant visited the various states, distributed and collected the completed copies of the questionnaire from the PTA executives and principals' of the public schools. Out of 3,583 copies distributed, 3,500 were correctly filled and returned thus giving a 98\% success. The data obtained were analyzed using mean and percentages to answer the research questions and t-test statistics to test the hypotheses at 0.05 level of significance. 


\subsection{RESULTS}

\subsection{Research Question One}

How do PTA members and principals perceive restitution for damages as principal's school plant management strategy?

Table 1: Perception on Restitution for Damages as Principals' School Plant Management Strategy.

\begin{tabular}{|c|c|c|c|c|c|c|c|}
\hline \multirow{3}{*}{$\mathbf{S} / \mathbf{N}$} & \multirow[b]{2}{*}{ Items } & \multicolumn{3}{|c|}{ PTA EXECUTIVES } & \multicolumn{3}{|c|}{ PRINCIPALS } \\
\hline & & \multirow[t]{2}{*}{ Mean x } & \multirow[t]{2}{*}{$\%$} & \multirow[t]{2}{*}{ Decision } & \multirow[t]{2}{*}{ Mean $x$} & \multirow[t]{2}{*}{$\%$} & \multirow[t]{2}{*}{ Decision } \\
\hline & The Principal & & & & & & \\
\hline 1 & $\begin{array}{l}\text { Often meets with } \\
\text { parents and } \\
\text { teachers. }\end{array}$ & 3.91 & 97.7 & SA & 4 & 100 & SA \\
\hline 2 & $\begin{array}{l}\text { Informs parents } \\
\text { and teachers on } \\
\text { the state of the } \\
\text { school equipment. }\end{array}$ & 3.8 & 90 & SA & 3.9 & 96 & SA \\
\hline 3 & $\begin{array}{l}\text { Insists that } \\
\text { students paying } \\
\text { for equipment } \\
\text { damaged }\end{array}$ & 4 & 100 & SA & 3.3 & 82.6 & SA \\
\hline 4 & $\begin{array}{l}\text { Enforces payment } \\
\text { for damaged } \\
\text { items }\end{array}$ & 3.94 & 98.5 & SA & 3.00 & 63 & A \\
\hline & Grand Total & 3.9 & 96.6 & SA & 3.4 & 85.3 & S.A \\
\hline
\end{tabular}

Key: (Agree: 4.00 - 3.00), (Disagree: $2.99-0.00$ )

$$
\text { Agree }=100 \%-50 \%, \text { Disagree }=1.49 \%-0 \%
$$

The result on table 1 shows respondents' perception on restitution for damages as principals' school plant management strategy. The result reveals that all the items were rated strongly agree. This implies that $96.6 \%$ of PTA executive members and $85.39 \%$ of principals' strongly agree in their perception. The result shows PTA executive members' grand mean of 3.9 and principals' grand mean of 3.4. 


\subsection{Research Question Two:}

How do PTA executive members and principals perceive effective monitoring as school plant management strategy?

Table 2: Perception on Effective Monitoring as School Plant Management Strategy.

\begin{tabular}{|c|c|c|c|c|c|c|c|}
\hline \multirow{3}{*}{$\mathbf{S} / \mathbf{N}$} & \multirow[b]{2}{*}{ Items } & \multicolumn{3}{|c|}{ PTA Executives } & \multicolumn{3}{|c|}{ Principals } \\
\hline & & Mean & $\%$ & Decisio & Mean x & $\%$ & Decision \\
\hline & Principal & $\mathbf{x}$ & & $\mathbf{n}$ & & & \\
\hline 5 & $\begin{array}{l}\text { Sets up monitoring } \\
\text { team for school } \\
\text { plant. }\end{array}$ & 4 & 100 & $\mathbf{S A}$ & 4 & 100 & $\mathbf{S A}$ \\
\hline 6 & $\begin{array}{l}\text { Gives guidelines for } \\
\text { monitoring school } \\
\text { plant. }\end{array}$ & 3.77 & 94.4 & $\mathbf{S A}$ & 3.3 & 82.6 & $\mathbf{S A}$ \\
\hline 7 & $\begin{array}{l}\text { Appoints a head of } \\
\text { the monitoring team. }\end{array}$ & 3.8 & 95.2 & $\mathbf{S A}$ & 3.07 & 63.0 & $\mathbf{A}$ \\
\hline 8 & $\begin{array}{l}\text { Mobilizes the } \\
\text { monitoring team } \\
\text { with money. }\end{array}$ & 4 & 100 & $\mathbf{S A}$ & 3.11 & 63.0 & $\mathbf{A}$ \\
\hline 9 & $\begin{array}{l}\text { Allows monitoring } \\
\text { team freehand to } \\
\text { work }\end{array}$ & 3.8 & 94.5 & $\mathbf{S A}$ & 3.4 & 85.9 & $\mathbf{A}$ \\
\hline 10 & $\begin{array}{l}\text { Requests monitoring } \\
\text { team to report } \\
\text { periodically to him. }\end{array}$ & 3.8 & 94.5 & $\mathbf{S A}$ & 4.0 & 100 & SA \\
\hline & Grand total & 3.86 & 96.4 & $\mathbf{S A}$ & 3.37 & 82.4 & $\mathbf{A}$ \\
\hline
\end{tabular}

Key: (Agree: 4.00 - 3.00), (Disagree: $2.99-0.00$ )

Agree $=100 \%-50 \%$, Disagree $=1.49 \%-0 \%$

The result on table 2 shows respondent's perception on effective monitoring as school plant management strategy. The result reveals that the grand mean of PTA is 3.86 and $96.4 \%$. On the principals' response, the grand mean is 3.3 and $82.4 \%$. This implies that the PTA executive members and principals agree to the effective monitoring as principals' school plant management strategy. 


\subsection{Research Question Three:}

How do PTA executive members and principals perceive setting aside equipment fee as school plant management strategy?

Table 3: Perception on Setting Aside Equipment Fee as School Plant Management Strategy.

\begin{tabular}{|c|c|c|c|c|c|c|c|}
\hline & & \multicolumn{3}{|c|}{ PTA EXECUTIVES } & \multicolumn{3}{|c|}{ PRINCIPALS } \\
\hline $\mathbf{S} / \mathbf{N}$ & Items & Mean $x$ & $\%$ & Decision & Mean $x$ & $\%$ & Decision \\
\hline 11 & $\begin{array}{l}\text { Government approves } \\
\text { payment of some fees } \\
\text { in school. }\end{array}$ & 3.96 & 99.2 & SA & 4 & 100 & SA \\
\hline 12 & $\begin{array}{l}\text { The fees are for } \\
\text { specific needs }\end{array}$ & 394 & 96.5 & SA & 4 & 100 & $\mathbf{S A}$ \\
\hline 13 & $\begin{array}{l}\text { Equipment fee is } \\
\text { approved by } \\
\text { Government. }\end{array}$ & 3.3 & 83.3 & $\mathbf{A}$ & 4 & 100 & SA \\
\hline 14 & $\begin{array}{l}\text { The fees are used to } \\
\text { maintain school } \\
\text { equipment. }\end{array}$ & 3.96 & 99.2 & SA & 2.1 & 42.6 & D \\
\hline 15 & $\begin{array}{l}\text { Principals divert } \\
\text { equipment fee for } \\
\text { other school needs. }\end{array}$ & 3.90 & 92.7 & SA & 2.0 & 43.6 & D \\
\hline 16 & $\begin{array}{l}\text { Principals set aside } \\
\text { equipment fee to } \\
\text { service school plant. }\end{array}$ & 2.03 & 42.6 & D & 2.7 & 48.7 & D \\
\hline & Grand total & 3.51 & 88.1 & SA & 3.1 & 70.3 & $\mathbf{A}$ \\
\hline
\end{tabular}

Key: (Agree: 4.00 - 3.00), (Disagree: 2.99-0.00)

Agree $=100 \%-50 \%$, Disagree $=1.49 \%-0 \%$

The result reveals that grand mean of PTA executive members is 3.51 and $88.1 \%$, while on the principal's response; the grand mean is 3.1 and $70.3 \%$. This implied that the PTA executive members and principals' strongly agree in their perception of setting aside the equipment fee as school plant management strategy. 


\subsection{Research Question Four:}

How do PTA executive members and principals perceive maintenance culture as school plant management strategy?

Table 4: Perception of Maintenance Culture as School Plant Management Strategy.

\begin{tabular}{|c|c|c|c|c|c|c|c|}
\hline \multirow{3}{*}{$\mathbf{S} / \mathbf{N}$} & \multirow{3}{*}{$\begin{array}{c}\text { ITEMS } \\
\text { The Principal }\end{array}$} & \multicolumn{3}{|c|}{ PTA EXECUTIVES } & \multicolumn{3}{|c|}{ PRINCIPALS } \\
\hline & & \multirow[t]{2}{*}{ Mean $x$} & \multirow[t]{2}{*}{$\%$} & \multirow[t]{2}{*}{ Decision } & \multirow[t]{2}{*}{ Mean $x$} & \multirow[t]{2}{*}{$\%$} & \multirow[t]{2}{*}{ Decision } \\
\hline & & & & & & & \\
\hline 17 & $\begin{array}{l}\text { Checks the school } \\
\text { plant regularly }\end{array}$ & 2.27 & 45.7 & D & 3.9 & 96.7 & SA \\
\hline 18 & $\begin{array}{l}\text { Identifies faulty } \\
\text { school plant. }\end{array}$ & 2.6 & 47.1 & D & 3.6 & 91.3 & SA \\
\hline 19 & $\begin{array}{l}\text { Sources out money } \\
\text { for repay of faulty } \\
\text { school plant. }\end{array}$ & 1.93 & 48.5 & SD & 3.4 & 85.9 & A \\
\hline 20 & $\begin{array}{l}\text { Identified school } \\
\text { plant that need } \\
\text { preventive } \\
\text { maintenance. }\end{array}$ & 3.75 & 93.9 & SA & 3.4 & 85.9 & A \\
\hline 21 & $\begin{array}{l}\text { The principal } \\
\text { identifies school } \\
\text { plant that need } \\
\text { shutting down } \\
\text { maintenance. }\end{array}$ & 2.56 & 45.8 & D & 3.2 & 80.4 & A \\
\hline 22 & $\begin{array}{l}\text { The principal } \\
\text { identifies any break } \\
\text { down in any } \\
\text { component. }\end{array}$ & 3.8 & 95.5 & SA & 3.2 & 80.4 & A \\
\hline & Grand Total & 2.8 & 48.6 & D & 3.45 & 86.8 & A \\
\hline
\end{tabular}

Key: (Agree: 4.00 - 3.00), (Disagree: $2.99-0.00$ )

Agree $=100 \%-50 \%$, Disagree $=1.49 \%-0 \%$

The result on table 4 shows perception of maintenance culture as school plant management strategy. The result reveals that PTA executive members have grand mean of 2.8 with a percentage of $48.6 \%$ while the principals' have grand mean of 3.45 and a percentage of $86.6 \%$. This implies that PTA executive members and principarts ${ }^{2}$.etisasgree 
in their perception of maintenance culture as school plant management strategy. The PTA executives do not believe that principals do enough to implement the maintenance culture practices whereas the principals claim to do so.

\subsection{Research Question Five:}

How do PTA Executives members and principals perceive setting up maintenance workshop as school plant management strategy?

Table 5: Perception of Setting up of Maintenance Workshop as School Plant Management Strategy

\begin{tabular}{|c|c|c|c|c|c|c|c|}
\hline \multirow{3}{*}{$\mathbf{S} / \mathbf{N}$} & \multirow[b]{2}{*}{ Items } & \multicolumn{3}{|c|}{ PTA EXECUTIVES } & \multicolumn{3}{|c|}{ PRINCIPALS } \\
\hline & & \multirow[t]{2}{*}{ Mean X } & \multirow[t]{2}{*}{$\%$} & \multirow[t]{2}{*}{ Decision } & \multirow[t]{2}{*}{ Mean X } & \multirow[t]{2}{*}{$\%$} & \multirow[t]{2}{*}{ Decision } \\
\hline & Principal & & & & & & \\
\hline 23 & $\begin{array}{l}\text { Sets up maintenance } \\
\text { workshop in school. }\end{array}$ & 2.56 & 45.7 & A & 1.17 & 40.8 & SD \\
\hline 24 & $\begin{array}{l}\text { Equips workshop } \\
\text { with maintenance } \\
\text { tools. }\end{array}$ & 1.93 & 48.5 & SD & 1.5 & 36.96 & SD \\
\hline 25 & $\begin{array}{l}\text { Gets junior staff to } \\
\text { do the maintenance } \\
\text { jobs }\end{array}$ & 2.27 & 46.7 & D & 2.7 & 46.5 & D \\
\hline 26 & $\begin{array}{l}\text { Ensures that the } \\
\text { staff work diligently }\end{array}$ & 1.93 & 48.5 & SD & 2.7 & 48.5 & D \\
\hline 27 & $\begin{array}{l}\text { Punishes any staff } \\
\text { who is lax in duty. }\end{array}$ & 2.27 & 46.7 & D & 2.7 & 50.5 & $\mathbf{A}$ \\
\hline 28 & $\begin{array}{l}\text { Raises funds from } \\
\text { public use of school } \\
\text { plant }\end{array}$ & 1.93 & 48.5 & SD & 2.7 & 49.5 & D \\
\hline 29 & $\begin{array}{l}\text { Appoints a manager } \\
\text { for the maintenance } \\
\text { workshop. }\end{array}$ & 1.93 & 48.5 & SD & 2.7 & 48.5 & D \\
\hline & Grand Total & 2.1 & 47.5 & D & 2.4 & 45.6 & D \\
\hline
\end{tabular}

Key: (Agree: 4.00 - 3.00), (Disagree: $2.99-0.00)$

Agree $=100 \%-50 \%$, Disagree $=1.49 \%-0 \%$

The result in table 5 shows respondents' perception on setting up of maintenance workshop as school plant management strategy. The result reveals that PTA executive members have grand mean of $2.1 \%$ and $47.5 \%$, while the principals have grand mean of 2.4 and $45.6 \%$. This implies that PTA executive members and principals' disagree with the idea of setting up of maintenance workshop as principals' school plant management strategy. 


\subsection{Research Question Six:}

How do PTA executive members and principals perceive community participation as school plant management strategy?

Table 6: Perception on Community Participation as Principal's School Plant Management Strategy.

\begin{tabular}{|c|c|c|c|c|c|c|c|}
\hline & & \multicolumn{3}{|c|}{ PTA EXECUTIVES } & \multicolumn{3}{|c|}{\begin{tabular}{|l} 
PRINCIPALS \\
\end{tabular}} \\
\hline $\mathbf{S} / \mathbf{N}$ & Items & $\overline{\text { Mean } \mathrm{x}}$ & $\%$ & Decision & Mean $x$ & $\%$ & Decision \\
\hline 30 & $\begin{array}{l}\text { The community has } \\
\text { skilled artisans } \\
\text { technicians. }\end{array}$ & 3.45 & 86.4 & $\mathbf{A}$ & 2.65 & 48.7 & D \\
\hline 31 & $\begin{array}{l}\text { The principal and } \\
\text { community exist in } \\
\text { harmony }\end{array}$ & 3.45 & 86.4 & $\mathbf{A}$ & 4 & 100 & $\mathbf{S A}$ \\
\hline 32 & $\begin{array}{l}\text { Principal solicits } \\
\text { community support } \\
\text { in plant maintenance }\end{array}$ & 2.56 & 64.2 & A & 3.43 & 85.9 & $\mathbf{A}$ \\
\hline 33 & $\begin{array}{l}\text { Community skilled } \\
\text { artisans and the } \\
\text { school form a } \\
\text { working committee }\end{array}$ & 3.75 & 93.9 & SA & 1.8 & 44 & SD \\
\hline 34 & $\begin{array}{l}\text { The joint committee } \\
\text { maintains school } \\
\text { plant. }\end{array}$ & 3.3 & 83.3 & $\mathbf{A}$ & 1.8 & 44 & SD \\
\hline 35 & $\begin{array}{l}\text { The principal } \\
\text { appreciates the } \\
\text { committee. }\end{array}$ & 3.3 & 83.3 & $\mathbf{A}$ & 2.5 & 45.3 & D \\
\hline & Grand Total & 3.38 & 84.9 & $\mathbf{A}$ & 2.69 & 47.3 & D \\
\hline
\end{tabular}

Key: (Agree: 4.00 - 3.00), (Disagree: 2.99-0.00)

Agree $=100 \%-50 \%$, Disagree $=1.49 \%-0 \%$

The result in table 6 shows the perception on community participation as school plant management strategy. The result reveals that PTA has grand mean of 3.38 and $84.9 \%$, while principals have grand mean of 2.69 and $47.3 \%$. This implies that PTA executive members and principals strongly agree in their perception on community participation as principal's school plant management strategy. 


\subsection{Hypothesis One:}

There is no significant difference in the perception of male and female PTA executive committee members on the use of community participation as principal's school plant management strategy.

Table 7: Summary of t-test Statistical Analysis on Male and Female PTA Executive Committee Members Perception on use of Community Participation as Principals' School Plant Management Strategy.

\begin{tabular}{|l|l|l|l|l|l|l|l|l|}
\hline Variable & No & $\mathbf{X}$ & SD & Df & $\begin{array}{l}\text { Sign } \\
\text { level }\end{array}$ & tcrtal & Tcal & Decision \\
\hline Female & 1800 & 15.7 & 6.1 & 3298 & 0.05 & 1.96 & 2.4 & HO \\
\hline Male & 1500 & 15.2 & 5.9 & & & & & Rejected \\
\hline
\end{tabular}

No $=$ Number

$\mathrm{X}=$ Mean

$\mathrm{SD}=$ Standard Deviation

Df $=$ Degree of freedom

Sign Level $=$ Level of significance

t Cal $=$ Calculated

$\mathrm{t} \mathrm{Cr}=$ Critical

$\mathrm{D}=$ Decision

Significant at 0.05 level; critical $\mathrm{t} \mathrm{cr}=1.96$; calculated $\mathrm{t}$ cal $=62.4 ; \mathrm{N}=3300$

Table 7 shows the result analyses on male and female PTA members' perception on use of community participation as school plant management strategy. The result reveals that there is significant difference in perception of male and female PTA executive members. The interpretation is derived from the analyses that $\mathrm{t}$ cal is 2.4 which exceeds the $\mathrm{t}$ cr of 1.96 . Therefore, the null hypothesis which states that there is no significant difference in the perception of male and female PTA executive members on use of community participation as school plant management strategy was rejected. The females are more in support of community participation than the males.

\subsection{Hypothesis Two:}

There is no significant difference in the perception of male and female PTA executive committee members on setting aside equipment fee as principal's school plant management strategy.

Table 8: Summary of t- test Analysis on Perception of Male and Female PTA Executive Committee Members on Setting Aside Equipment Fee as Principal's School Plant Management Strategy.

\begin{tabular}{|lllllllll|}
\hline Variables & No & $\mathbf{X}$ & SD & Df & $\begin{array}{c}\text { Sign } \\
\text { level }\end{array}$ & tcrtal & Tcal & Decision \\
\hline Female & 1800 & 16.2 & 5.5 & 3298 & 0.05 & 1.96 & 15.6 & HO \\
Male & 1500 & 19 & 4.5 & & & & & Rejected
\end{tabular}

Significant at 0.005 level, critical $t=1.96$, calculated $t=15.6, N=3300$ 
The result on table 8 shows the analysis of male and female PTA executive members' perception on setting aside equipment fee as school plant management strategy. The result reveals that there is significant difference on perception of male and female PTA executive members on setting aside equipment fee as school plant management strategy. This interpretation is derived from the analysis that $\mathrm{t}$ cal is 15.6 exceed the $\mathrm{t}$ cr value of 1.96. The null hypothesis which states that there is no significant difference on the perception of male and female PTA executive members on setting aside equipment fee as school plant management strategy was therefore rejected. The males are more in support of the strategy than the females.

\subsection{Hypotheses Three:}

There is no significant difference in the perception of Imo and Anambra states PTA executive committee on principals' school plant management strategies.

Table 9: Summary of t-test Statistical Analysis on the Perception of Imo and Anambra States PTA Executive Committee members on Principals' School plant Management Strategies.

\begin{tabular}{lcccccccc|}
\hline Variables & No & $\mathbf{X}$ & SD & $\begin{array}{c}\text { Sign } \\
\text { level }\end{array}$ & df & tcr & tcal & Decision \\
\hline $\begin{array}{l}\text { Anambra } \\
\text { State }\end{array}$ & 700 & 101.1 & 19.3 & 0.05 & 1448 & 1.96 & 5.1 & $\mathrm{HO}$ \\
Imo State & 750 & 95.5 & 20.9 & & & & & Rejected \\
\hline
\end{tabular}

Significant at 0.005 level, critical $t=1.96$, Calculated $t=5.1, N=1450$

Table 9 shows the result of analysis on perception of Imo and Anambra states PTA executive members on principals' school plant management strategies. The results reveal that there is significant difference as interpreted from the analysis that $\mathrm{t}$ cal is 5.1 which exceeds the $\mathrm{t} \mathrm{cr}$ of 1.96. Therefore, the null hypothesis which states that there is no significant difference in perception of Imo and Anambra states PTA executive members on school plant management strategies was rejected. Anambra state PTA executives are more in support of the strategy than their Imo state counterparts. 


\subsection{DISCUSSION}

The result on table 1 was rated "Strongly Agree". This implied that PTA executive members and principals' strongly agree in their perception of restitution for damages as school plant management strategy. This finding agree with the work of Amanchukwu et al. (2015) and Okafor (2003) who suggested that students should pay for any equipment they damaged in the school. Sometimes, these decisions were taken in PTA meetings and principals' with good leadership traits implement them fully. When students know that they will pay for the damaged equipment, they will reduce the rate of vandalism of school plants. They cannot escape the payment since they must collect their certificates. The result of data analysis on table 2 was rated "Strongly Agree". This implied that PTA executive members and principals' strongly agree in their perception of effective monitoring of school plant as school plant management strategy. The finding agree with the work of Amanchukwu and Ololube (2015) who found that school plants require an effective monitoring culture, and that setting up a monitoring team in every institution to check the school plant and users and also writing an official report about the finding would help the school plant last longer and remain valuable for effective use.

Nwokike (2012) found that principals play significant roles in procurement, maintenance, safe guarding and ensuring adequate utilization of school plant. Okorie et al (2014) also opined that the principals' has the responsibility of routine facility check to, maintain or replace those in bad condition. Aguilar (2015) averred that principals' teachers and parents should be vigilant, guard and be aware of students' activities while Uko (2015) viewed that government should set up committees or agencies to oversee, supervise and maintain the school facilities. The result of data analysis on table 3 was rated "Strongly Agree". This implies that the PTA executive members and principals' strongly agreed in their perception of setting aside equipment fee as school plant management strategy. This finding agrees with Amanchukwu et al. (2015) who found that principals set aside equipment fee as school plant management strategy. Asodike et al. (2015) also agreed that communities should pay required fee which could be used to procure more and new facilities for maintenance.

Agoha (2008) suggested that government should build in maintenance cost in the education budget. The result of data analysis on table 4 was rated "Disagree". This implied that PTA executive and principals disagree in their perception of maintenance culture as school plant management strategy. This finding agreed with Okorie et al (2014) who opined that school principals and teachers that use the facilities lack the maintenance culture, but maintained that school environment should be kept clean and safe and that lack of maintenance culture is responsible for the ageing and deterioration of school building and equipment. This finding does not agree with the work of Amanchukwu et al. (2015) who found that principals' enhance maintenance culture of students and teachers by keeping the classroom and environment clean and tidy and that maintenance culture should be part and parcel of institutions of learning. Uko (2015) held that principals, teachers and students should imbibe maintenance culture in the handling of facilities generally. The difference in the finding may be as a result of situation and condition in the society. 
Government no longer provides running cost to the administration of schools as before. This leads to nonchalant attitudes of some principals who do not care whether the school plant are deteriorating or collapsing. The result on data analysis on table 5 was rated "Disagree". This implied that the PTA executive and principals disagree in their perception of setting up of maintenance workshop as school plant management strategy. The finding agrees with Ejikeme (2000) who found that there were no more workshop officers in charge of physical facilities and equipment as government no longer recruits officers to maintain the school plant. This implied that setting up of maintenance workshop is no longer a strategy the principal could adopt since the principal could not afford to pay the officers and skilled men from his own pocket. This also agrees with Agenyi, Idoko and Agenyi (2015) who found that in recent times, efforts in the best ways made by government and individuals to encourage school plant maintenance have been on upgrading of facilities and employing specialist to oversee them. This also agrees with Okafor (2003) cited in Agoha (2008) who recommended that post primary school management board should employ store officers and other workers to be in charge of school plant maintenance, repairing and distribution of school plant. But this study does not agree with Amanchukwu et al (2015) who suggested that maintenance workshop should be instituted in schools. The result of data analysis on table 6 was rated "Strongly Agree". This implied that the PTA executives and principals strongly agree in their perception of community participation as school plant management strategy. This finding agreed with Amanchukwu et al (2015) who found that principals should mobilize community and philanthropists to assist in school plant management. Okafor (2005) cited in Agoha (2008) stated that the community in which the school is located sometimes refurbishes school plants. Obiadozie (2014) also revealed that communities would be involved in funding facilities through PTA levies, encouraging age grades, alumni and groups to embark on projects, donations from philanthropists and organizing fund raising ceremonies. Tshsbalala (2013) stated that parents are expected to contribute to the provision and management of the school facilities and raise funds for the project development.

With respect to hypothesis one, although both male and female PTA executives supported the principals' strategy of community participation, the female members were significantly more supportive. That could result from the greater enthusiasm usually expressed by females about the quality of education their children receive. In most cases, female executive members of PTAs are experienced, knowledgeable and capable hands who appreciate the value of quality education. Their male counterparts may not be as knowledgeable but may be appointed/elected on grounds of their wealth and influence in the community.

For hypothesis 2, male PTA executives were more in support of setting aside equipment fee as part of the principals' plant management strategy. It would appear that females are often suspicious of male in matters of fund management. That may explain why female PTA executives were less enthusiastic than their males colleagues in supporting this strategy.

The third hypothesis indicates that Anambra state PTA executives are most in support of the principal's school plant management strategies than their Imo state counterparts. Anambra state is known in the South-East of Nigeria as the state where many of the boys refuse to go 
to school but prefer trading. Parents are obviously hurt by this situation and would be more enthusiastic than Imo people to institute strategies that would guarantee better quality education.

\subsection{CONCLUSION AND RECOMMENDATIONS}

School plants contribute significantly to effective teaching and learning in schools in order to achieve the stated organizational goals. It has been seen that management of school plant has been affected by some factors which include; principals' management strategies, PTA management of school plant and school location and size. If school principals can improve on these areas, the educational landscape of the secondary school in south east states of Nigeria will be improved. It is recommended that principals should adopt maintenance culture as a strategy and that government should encourage the payment of equipment fee and established maintenance workshop in schools 


\section{REFERENCES}

Agboneye, C. O. (2006). Physical facilities in secondary schools in Owerri education zone of Imo State. IMSU (unpublished M.ED thesis ).

Agenyi, E; Idoko, C. U.\& Agenyi, R. M.(2015). Maintaining school plant for national transformation. SSRG International Journal of Economic and Management Studies S S P G- IJEMS, .2, 2.(p.1-8)

Agoha, R. C.(2008), Administrative strategies for school plant maintenance in secondary schools in Okigwe zone. Retrieved 11 $1^{\text {th }}$ July, 2017, from www.un.ed.ng//.../...(unpublished UNN m.ed.thesis)

Aguilar, S.(2015). School plant management. Retrieved $11^{\text {th }}$ July, 2017,from

Olga-schoolplantmgt.blogstot.com. Google.

Amanchukwu, N. \& Ololube, N. P.(2015). Managing school plant for effective service delivery in secondary schools in Rivers State. Human Resource Management Research, 5(4); 95-105. Dol: 105923/ jhrmr. 20150504.02

Asiabaka, I. P.(2008). The need for effective facility management in schools in Nigeria. New York Science Journal. 1(2) 10-21. Retrieved $26^{\mathrm{TH}}$ February, 2016, from http://www.science Pub. Org. ISSN 1554-0200.

Asodike, D. J., Ebong, M. T., Oluwuo, S. O. \& Abraham, N.M. (eds) (2013). Contemporary administration and teaching Issues in Nigeria schools. Owerri. Alphabet Nigerian Pubs.

Ejikeme, C. N. (2000). Management of physical facilities and equipment in secondary schools in Onitsha education zone. Unpublished M.ed. thesis. University of Nigeria, Nsukka.

Ezeigbo, J. (2011). Key note- address delivered at Government Secondary Technical School Owerri to Scholarship Awardees by P.T.A. in Asodike,D.J., Ebong,M.T., Oluwuo, S.O. \& Abraham, N.M. (eds)(2013) Contemporary administration and teaching issues in Nigeria schools. Owerri. Alphabet Nigerian Pubs.(p.291).

Eziuzo, G. O. \& Enueme, C.P.(2013).Contribution of Parent-Teachers Association to secondary school management: Principals' perception. Journal of Emerging Trends in Educational Research and Policy-Studies (JETERAPS), 4(6),(p. 835-841).

Federal Republic of Nigeria (2013). National Policy on Education. Lagos: NERDC Press.

Idoko, A. A. (2005). Understanding School Management. Markurdi: Ugo Printing Press.

Koroye,T.(2016). The Influence of school physical environment of secondary school student's academic performance in Bayelsa State. Asian Journal of Educational Research.4, (.2).(p.17-24).

Mbipom, G.(2010). Educational administration \& planning. In T. Koroye (ed) The influence of school physical environment of secondary school student's academic performance in Bayelsa State. Asian Journal of Education Research, 4. (2).(p.17-24). 
Meghan, M. V.(2001). A Principal's role in opening new school'. University of Georgia(unpublished Ph.D thesis).

Nwokike, S. C.(2012). Management of school plant by principals in Nsukka education zone of Enugu State. UNN (Unpublished Ph.D. thesis).

Nwosu, Osita. (2008). Educational planning and management: Concepts, insights and critiques. Onitsha: Osyora Nigeria Limited.

Obiadozie, R.E.(2014). Strategies for involving communities in funding of computer education in schools in Anambra State. Africa Research on Computer Participation. An International Multidisciplinary Journal, Ethiopia: 8 (1) serial no. 32,(p.64-82)

Ogili, E. (2009). Community development for new Africa. In T. Koroye(ed), The influence of school physical environment of secondary school student's academic performance in Bayelsa State. Asian Journal of Educational Research .4.(.2).(p.1-5).

Okafor, F. O. (2003). Evaluation of school plant adequacy, usage and maintenance in secondary schools in Idemili north L.G.A. UNN (unpublished M.Ed thesis). In R. C. Agoha(ed), Administrative strategies for school plant maintenance in secondary schools in Okigwe zone. Pp.12-91. Retrieved July, 2017 from www.un.ed.ng/../..unpublished (UNN m.ed. thesis)

Okendu, J. N. (2012). The role of school board, school heads and PTA in effective management of public secondary schools. Journal of Education and Practice, 3.(8).(p.201-207).

Okorie, N. C., Igwe, L.E.B., Asodike, J. D., Onyeike, V. C. and Anyaogu, R. O. (2014). Teacher, school and society. Port- Harcourt: Pearl Pub. Books.

Olagboye, A .A. (2004). Introduction to educational management in Nigeria. Ibadan: Daily Graphics.

Onderi, H. \& Makori, A. (2013). Training needs of board of governors and PTA on school leadership and management in Kenya secondary education. A study of district in the Kisii county of Kenya. Global Advanced Research Journal of Social Science 2.(3),(064-077).

Tshabalala, T. (2013). Perception of school heads on parents involvement in the Zimbawean primary schools. International Journal of Asian Social Studies, 3(3),645-65

Uko, E.S. (2015). Principalship and effective management of facilities in secondary schools in Cross River State. Nigeria. International Journal of Academic Research and Reflection. 3, (1), (p.1-13). 